\title{
PEMBERDAYAAN EKONOMI KELOMPOK WANITA TANI SAUYUNAN DI DESA DUNGUSWIRU, KECAMATAN BL. LIMBANGAN, KABUPATEN GARUT
}

\author{
ECONOMIC EMPOWERMENT OF SAUYUNAN WOMEN FARMER'S GROUP \\ IN DUNGUSWIRU VILLAGE, BL. LIMBANGAN SUBDISTRICT, GARUT DISTRICT
}

\author{
Ane Novianty*, Agus Yuniawan Isyanto, Benidzar M. Andrie \\ Fakultas Pertanian, Universitas Galuh \\ *Email: Noviantyane29@gmail.com \\ (Diterima 27-03-2020; Diterima 31-03-2020)
}

\begin{abstract}
ABSTRAK
Kegiatan pengabdian kepada masyarakat ini dilakukan pada Kelompok Wanita Tani (KWT) Sauyunan Desa Dunguswiru Kecamatan Bl. Limbangan Kabupaten Garut dengan tujuan untuk: (1) Menumbuhkan motivasi kewirausahaan anggota kelompok, (2) Pelatihan penggunaan pola tanam vertikultur, dan (3) Perijinan pemanfaatan lahan di sepanjang jalan perdesaan. Kegiatan pengabdian ini diikuti oleh seluruh anggota KWT Sauyunan sebanyak 25 orang. Tim pengabdian kepada masyarakat bertindak sebagai fasilitator dan melakukan pendampingan agar para anggota kelompok memiliki jiwa wirausaha yang tinggi sehingga mampu mengelola usahataninya yang berorientasi pasar. Selain itu, mitra telah mengetahui cara bercocok tanam vertikultur untuk optimalisasi pemanfaatan pekarangan. Upaya peningkatan produksi dilakukan dengan pemanfaatan lahan sepanjang jalan desa sepanjang 200 meter yang dapat ditanami 1.000 polybag.
\end{abstract}

Kata kunci: Kelompok wanita tani, vertikultur, pemanfaatan jalan desa

\begin{abstract}
Community service activities were carried out at the Sauyunan Women Farmer's Group in Dunguswiru Village, Bl Limbangan District, Garut District with the aim to: (1) Foster entrepreneurial motivation of group members, (2) Training in the use of verticultural planting patterns, and (3) Licensing of land use along rural roads. This activity was attended by all 25 group members. The community service team acts as a facilitator and provides assistance so that group members have a high entrepreneurial spirit so that they are able to manage their market-oriented farming. In addition, partners already know how to grow verticulture to optimize yard use. Efforts to increase production are carried out by utilizing land along 200 meters of village roads that can be planted with 1,000 polybags.
\end{abstract}

Keywords: Women farmer's group, verticulture, utilization of village roads

\section{PENDAHULUAN}

Seiring dengan peningkatan jumlah penduduk dan perkembangan struktur perekonomian, kebutuhan lahan untuk kegiatan non pertanian cenderung terus meningkat. Penggunaan lahan yang meningkat oleh manusia, seperti untuk tempat tinggal, tempat melakukan usaha, pemenuhan akses umum dan fasilitas lain akan menyebabkan lahan yang tersedia semakin menyempit. Kecenderungan tersebut menyebabkan alih fungsi lahan pertanian sulit dihindari (Lapatandau, dkk, 2017).

Secara makro, berubahnya fungsi lahan tersebut akan mengurangi luasan lahan pertanian yang dapat menjadi penyebab berkurangnya produksi pangan. Secara mikro, pada tingkat rumah tangga, alih fungsi lahan dapat menjadi penyebab terjadinya berkurangnya kepemilikan lahan, berkurangnya persediaan pangan dan perubahan struktur pekerjaan (Janah, dkk, 2017). 
Pemberdayaan Ekonomi Kelompok Wanita Tani Sauyunan di Desa Dunguswiru,

Menyikapi hal tersebut, diperlukan upaya pemberdayaan masyarakat untuk menanggulangi dampak lingkungan dan sosial ekonomi masyarakat. Pada hakekatnya, pemberdayaan merupakan suatu kegiatan yang lebih menekankan kepada proses, sehingga partisipasi atau keterlibatan masyarakat dalam setiap tahapan pemberdayaan mutlak diperlukan (Endang, dkk, 2017).

Salah satu cara untuk menanggulangi dampak sosial ekonomi masyarakat tersebut dapat dilakukan dengan pemberdayaan kelompok wanita tani (KWT). KWT merupakan salah satu wadah bagi para petani wanita yang berbeda dengan kelompok tani lainnya. Dalam pembinaannya, KWT diarahkan untuk mempunyai suatu usaha produktif dalam skala rumah tangga yang diharapkan dapat meningkatkan kesejahteraan keluarganya (Kirana, dkk, 2018).

KWT Sauyunan berlokasi di Kampung Babakan Desa Dunguswiru Kecamatan B1. Limbangan Kabupaten Garut. KWT Sauyunan dibentuk untuk menjadi pelaku usaha yang berbasis pada ekonomi kerakyatan, mengolah hasil pertanian yang tentunya akan meningkatkan nilai tambah dan nilai estetika bagi produk pertanian. Kegiatan yang biasa dilakukan oleh KWT ini adalah pemanfaatan pekarangan untuk konsumsi rumah tangga. Namun, pemanfaatan pekarangan ini dinilai kurang meningkatkan pendapatan keluarga, sehingga dibutuhkan cara lain untuk dapat mencapai target yang diharapkan. Permasalahan yang dihadapi KWT ini adalah keterbatasan lahan yang dimiliki, sehingga berpengaruh terhadap produktivitas yang dihasilkan.

Tujuan kegiatan pengabdian masyarakat ini adalah 1) Penyuluhan motivasi sumberdaya manusia; 2) Pelatihan penggunaan pola tanam vertikultur; 3) Perijinan pembukaan lahan di sepanjang jalan perdesaan.

\section{BAHAN DAN METODE}

\section{Waktu dan Lokasi}

Kegiatan ini dilaksanakan pada bulan Desember 2019 - Januari 2020. Lokasi kegiatan sesuai dengan lokasi kelompok mitra, yaitu di Kampung Babakan Desa Dunguswiru Kecamatan B1. Limbangan Kabupaten Garut.

\section{Metode Pelaksanaan}

Pelaksanaan abdimas kepada mitra dilakukan berdasarkan analisis situasi dan permasalahan yang ditemukan pada mitra. Berdasarkan kesepakatan antara tim dan mitra untuk mendapatkan solusi permasalahan, maka metode yang digunakan adalah pelatihan dengan tujuan untuk meningkatkan pengetahuan dan keterampilan budidaya tanaman untuk 
optimalisasi lahan terbatas di perdesaan. Langkah-langkah yang ditempuh dalam kegiatan ini meliputi beberapa tahap berikut ini:

1. Tahap Penyuluhan

Penyuluhan dilakukan kepada seluruh anggota aktif KWT Sauyunan yang berjumlah 25 orang. Metode penyuluhan menggunakan metode ceramah dengan materi motivasi anggota KWT sebagai SDM penggerak peningkatan pendapatan keluarga.

2. Tahap Pelatihan dan Keterampilan

Pelatihan dilakukan di posko KWT Desa Dunguswiru dengan peserta seluruh anggota KWT yang berjumlah 25 orang. Pelatihan yang diberikan adalah mengenai pembuatan rak vertikultur. Pelatihan ini penting untuk diketahui oleh masing-masing anggota kelompok untuk bekal kedepan menciptakan kemandirian usahatani. Harapannya setelah diberi pelatihan, anggota KWT ini dapat memberikan informasi dan pengalaman kepada masyarakat untuk ikut serta menghijaukan lingkungan yang berdampak pada peningkatan pendapatan.

3. Tahap Perijinan Pembukaan Lahan di Sepanjang Jalan Perdesaan

Melakukan kerjasama dengan pemerintah desa untuk membuka lahan tanam sepanjang jalan perdesaan. Lahan yang digunakan adalah area pinggir jalan desa dan lahan terbengkalai. Optimalisasi lahan ini bertujuan untuk menambah area tanam selain pekarangan, sehingga meningkatkan produktivitas.

\section{HASIL DAN PEMBAHASAN}

KWT Sauyunan berlokasi di kampung Babakan Desa Dunguswiru Kecamatan Bl.Limbangan Kabupaten Garut. KWT ini telah dirintis sejak 2010 dengan jumlah anggota aktif sebanyak 64 orang. Kegiatan KWT ini adalah memanfaatkan pekarangan sebagai bagian dari kegiatan masyarakat tidak sebatas untuk konsumsi keluarga, tetapi juga diharapkan dapat berkembang menjadi rumah tangga dalam meningkatkan pendapatan keluarganya.

\section{Penyuluhan Motivasi Berwirausaha}

Kemampuan berwirausaha merupakan suatu hal yang sangat diperlukan. Kewirausahaan tidak hanya dapat dipahami sebagai kemampuan untuk membuka usaha sendiri, namun harus juga dapat dimaknai sebagai momentum untuk mengubah mentalitas, pola pikir dan perubahan sosial budaya (Purnomo, 2017). Keberlanjutan usaha akan berhasil jika para peserta dapat memahami tentang arti penting wirausaha. Pelatihan motivasi berwirausaha dihadiri 15 orang peserta dari anggota KWT Sauyunan. Pada kegiatan ini para peserta 
Pemberdayaan Ekonomi Kelompok Wanita Tani Sauyunan di Desa Dunguswiru,

Kecamatan Bl. Limbangan, Kabupaten Garut

Ane Novianty, Agus Yuniawan Isyanto, Benidzar M. Andrie

diberikan pengetahuan tentang pentingnya berwirausaha, menumbuhkan jiwa kewirausahaan (Wijatno, 2009), dan keunggulan produk lokal. Foto kegiatan pelatihan disajikan pada Gambar 1.

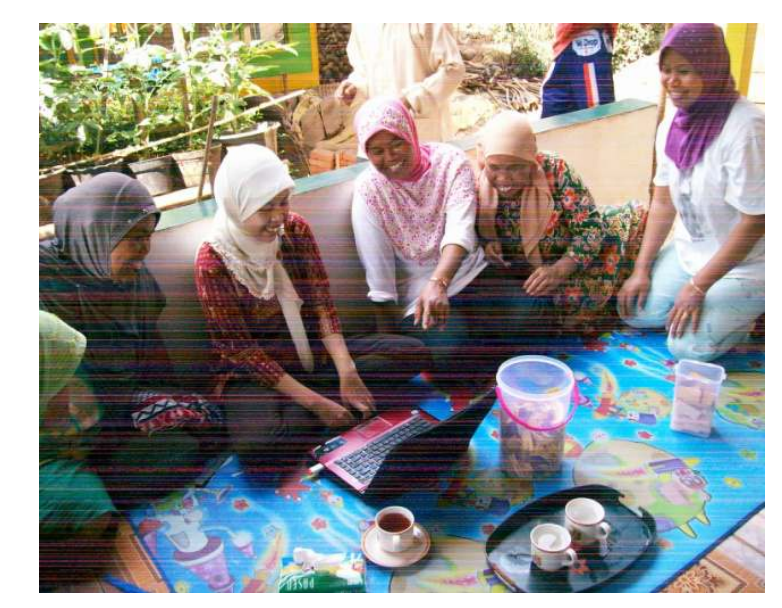

\section{Gambar 1. Pelatihan Motivasi Berwirausaha}

Secara umum, materi penyuluhan membahas mengenai pentingnya berwirausaha, bagaimana memulai wirausaha, dan berwirausaha. Penyuluhan dilakukan dengan metode ceramah dan dilanjutkan dengan diskusi. Materi penyuluhan terdiri atas sikap, perilaku, upaya untuk mencari, menciptakan, teknologi, produk baru dan peningkatan efisiensi.

Pre test dan post test dilakukan untuk mengetahui peningkatan pengetahuan dari para peserta penyuluhan. Hasil pre test dan post test diketahui bahwa peserta mengalami peningkatan pengetahuan setelah mengikuti penyuluhan. Hal ini dapat dilihat dari skor post test yang lebih tinggi dari hasil pre test. Berdasarkan hasil tersebut dapat dipahami karena peserta belum pernah memperoleh motivasi berwirausaha selama mereka tergabung dalam KWT. Penyuluhan berwirausaha adalah solusi untuk membentuk pola pikir peserta yang tadinya biasa saja menjadi sesuai standar wirausaha. Selain itu, penyuluhan ini dapat membentuk wirausaha yang siap secara mental dan finansial yang dapat bersaing di pasar bisnis. Hal ini sejalan dengan pendapat Valerio (2014) yang menyatakan bahwa pelatihan kewirausahaan sebagai program yang cenderung fokus dalam membangun pengetahuan dan keterampilan secara eksplisit dalam persiapan untuk memulai suatu usaha, dimana dalam program pelatihan ini, menuntun peserta untuk terlibat dalam praktek. 


\section{Pelatihan Pembuatan Media Tanam Vertikultur untuk Pekarangan}

Vertikultur dapat diartikan sebagai teknik budidaya tanaman secara vertikal sehingga penanaman dilakukan secara bertingkat. Pemanfaatan teknik vertikultur ini memungkinkan untuk berkebun dengan memanfaatkan tempat secara efisien. Secara estetika, taman vertikultur berguna sebagai penutup pemandangan yang indah dengan berbagai warna (Ati dan Solikhah, 2015). Pembuatan vertikultur tidak selalu harus menggunakan bahan yang mahal, namun dapat juga menggunakan bahan yang mudah ditemukan di perdesaan ataupun penggunaan barang bekas. Vertikultur di desain untuk memunculkan nilai estetika lingkungan dan juga mengikuti kaidah syarat pertumbuhan tanaman, yaitu mendapatkan sinar matahari dan air yang cukup. Model vertikultur yang digunakan adalah rak bambu dan pot gantung, mengingat bahwa Desa Dunguswiru banyak dikelilingi kebun bambu sehingga tidak sulit untuk mendapatkan bahan baku pembuatan rak. Foto pembuatan rak vertikultur untuk pekarangan disajikan pada Gambar 2.

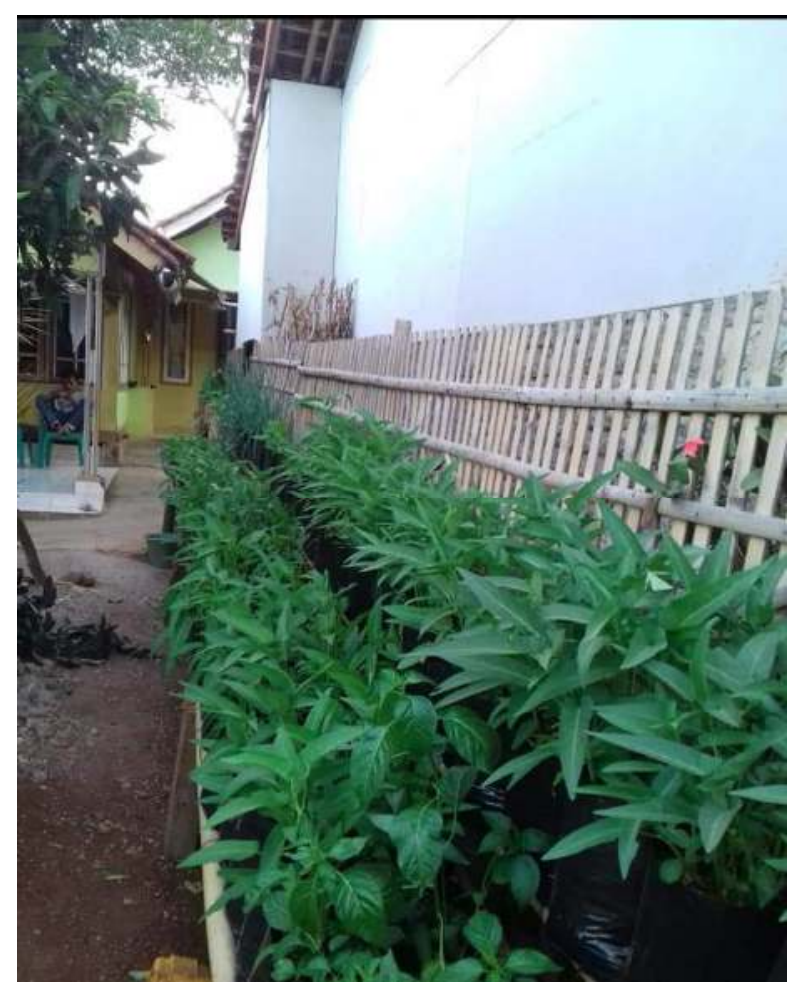

Gambar 2. Rak Vertikultur

Pelatihan ini mencakup pemberian gambaran mengenai desain dan dimensi sesuai dengan kebutuhan ruang yang digunakan. Sesuai dengan pernyataan Mohamad dan Mirajuddin (2013), bahwa persyaratan aplikasi teknologi vertikultur yang harus dipenuhi dalam budidaya di lahan pekarangan yang sempit adalah harus memiliki nilai estetika atau keindahan, sehingga selain dapat menghasilkan tanaman sehat dan bergizi untuk dikonsumsi, 
Pemberdayaan Ekonomi Kelompok Wanita Tani Sauyunan di Desa Dunguswiru,

Kecamatan B1. Limbangan, Kabupaten Garut

Ane Novianty, Agus Yuniawan Isyanto, Benidzar M. Andrie

juga dapat memperindah halaman rumah. Selain itu, persyaratan lainnya adalah bahan harus kuat dan mudah untuk dipindahkan.

\section{Proses Pembukaan Jalan Perdesaan Sebagai Lokasi Penanaman}

Pembukaan jalan perdesaan sebagai lokasi penanaman dimaksudkan untuk menambah luas areal pertanaman sehingga diharapkan akan menambah penghasilan masyarakat, khususnya anggota KWT aktif. Mubyarto (1989) menyatakan bahwa lahan adalah salah satu faktor produksi, tempat dihasilkannya produk pertanian yang memiliki sumbangan yang cukup besar terhadap usahatani, karena banyak sedikitnya hasil produksi dari usahatani sangat dipengaruhi oleh luas sempitnya lahan yang digunakan. Selain itu, penanaman tanaman di pinggir jalan desa dapat juga menjadi salah satu upaya pelestarian lingkungan. Pemanfaatan lahan yang dilakukan adalah budidaya jahe, budidaya tanaman sayuran, dan budidaya tanaman kunyit yang memiliki nilai ekonomis. Kegiatan pembukaan jalan desa sebagai area pertanaman tersaji pada Gambar 3.

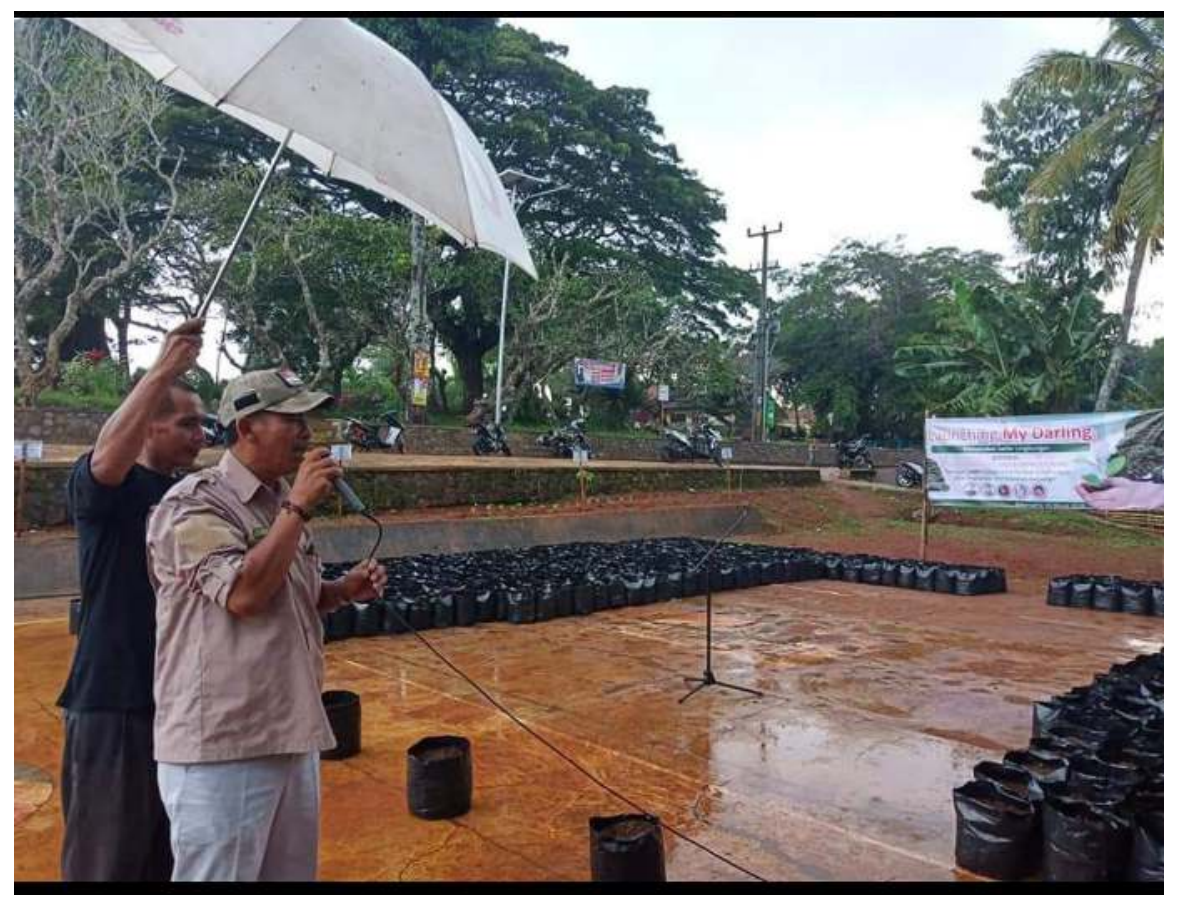

Gambar 3. Pembukaan Jalan Perdesaan Sebagai Area Pertanaman

Jalan desa yang digunakan adalah jalan utama Desa Dunguswiru sepanjang 200 meter. Kegiatan ini dapat berlangsung dengan antusias yang tinggi dari Kepala Desa Dunguswiru, anggota KWT Sauyunan, dan masyarakat Desa Dunguswiru. 


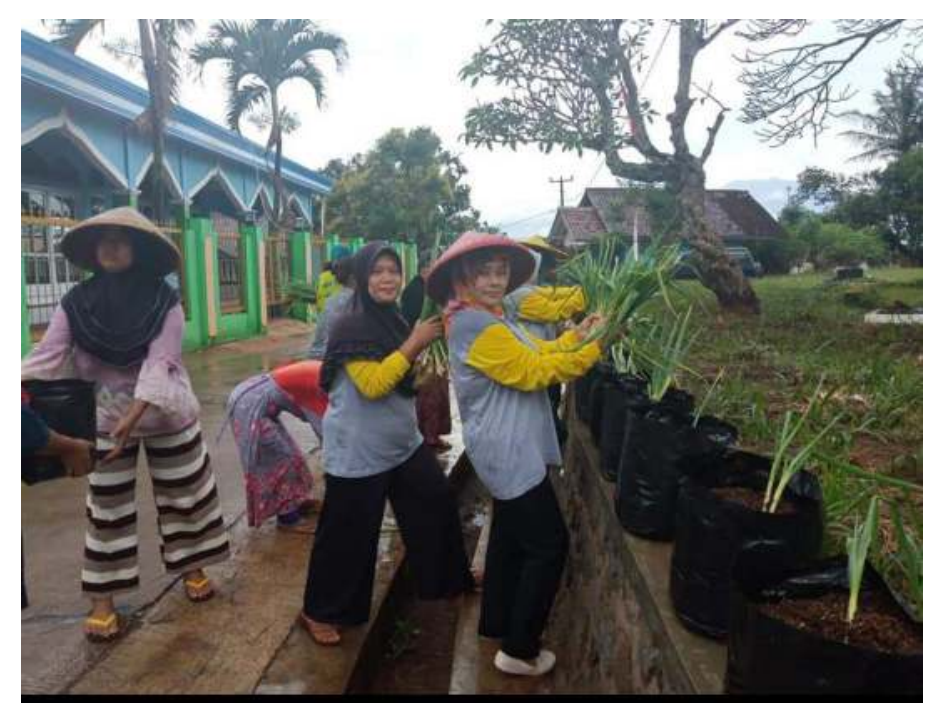

\section{Gambar 4. Kegiatan Penanaman Tanaman di Sepanjang Pinggir Jalan Desa}

Dengan bergotong royong, para anggota KWT memenuhi setiap pinggir jalan desa dengan tanaman yang telah direncanakan sebelumnya. Jumlah tanaman yang diperlukan untuk memenuhi 200 meter area pinggir jalan tersebut sebanyak 1.000 polybag. Menurut Ambarita dan Kartika (2015), sesuai dengan teori yang ada, jika semakin besar luas lahan makan semakin besar produksi yang dihasilkan.

\section{KESIMPULAN}

Program pemberdayaan masyarakat anggota KWT Sauyunan melalui pemanfaatan vertikultur dan pembukaan jalan desa sebagai areal pertanaman telah dapat meningkatkan motivasi mitra untuk berusaha dan berwirausaha dalam mengembangkan usahatani, melakukan optimalisasi lahan pekarangan dengan vertikultur, serta mampu membuka lahan pinggir jalan desa sebagai area usahatani untuk meningkatkan produktivitas dan pendapatan anggota KWT khususnya.

\section{DAFTAR PUSTAKA}

Ambarita, K dan Kartika, N. 2015. Pengaruh Luas Lahan, Penggunaan Pestisida, Tenaga Kerja, Pupuk Terhadap Produksi Kopi di Kecamatan Pekutatan Kabupaten Jembrana. E-Jurnal Ekonomi Pembangunan Universitas Udayana, 4(7):16-29.

Ati, K dan Solikhah, U. 2015. Peningkatan Pendapatan Keluarga Melalui Pemanfaatan Pekarangan Rumah dengan Menggunakan Teknik Vertikultur. Jurnal Inovasi dan Kewirausahaan, 4(2):94-101. 
Endang, W.M., Darini, S.U., dan Prihatiningsih, N. 2017. Pemberdayaan Kelompok Wanita Tani Melalui Optimalisasi Pemanfaatan Pekarangan dengan Budidaya Sayuran Organik Dataran Rendah Berbasis Kearifan Lokal dan Berkelanjutan. Jurnal Pengabdian dan Pemberdayaan Masyarakat LPIP UMP, 1(2):147-154.

Janah. R, B.T. Eddy, dan T. Dalmiyatun. 2017 Alih Fungsi Lahan Pertanian dan Dampaknya Terhadap Kehidupan Penduduk di Kecamatan Sayung Kabupaten Demak. Jurnal Agrisocioeconomics, 1(1):1-10.

Mohamad, H dan Mirajuddin, M. 2013. Pendampingan Pembuatan Media Vertikultur untuk Penanaman Tumbuhan Obat dalam Pemaksimalan Pekarangan Rumah. Jurnal Inovasi dan Kewirausahaan, 2(2):82-87.

Mubyarto. 1989. Pengantar Ekonomi Pertanian. Jakarta: LP3ES.

Purnomo, B.R. 2017. Efektifitas Pelatihan Kewirausahaan dalam Meningkatkan Pengetahuan dan Motivasi Berwirausaha pada Penyandang Tunarungu. Jurnal Ekspektra, 1(1):21-30.

Valerio, A. P dan B. Robb. 2014. Entrepreneurship Education and Training Program Around the World: Dimension for Succcess. Washington D.C: The World Bank.

Wijatno, S. 2009. Pengantar Entrepreneurship. Jakarta: Grasindo. 